\title{
Contribution of Balanced Scorecard Implementation in Performance Management System to Enhance Job Satisfaction: Empirical Evidence from FMCG Sector of Pakistan
}

\author{
Sophia Khalid ${ }^{1}$, Ansar Waseem $^{2}$
}

\begin{abstract}
Many conglomerates employ various performance measurement tools to monitor the performance of their employees. Most of these performance measures only concentrate on the financial dimension of the performance. The balanced scorecard is one such tool that measures the performance of a firm along multiple dimensions. This study investigated the implementation of a balanced scorecard in the performance measurement system of the FMCG Sector of Pakistan and measured its impact on employee satisfaction. To achieve this objective, a quantitative study was designed on FMCGs and primary data was gathered using a Likert scale questionnaire administered to 218 respondents. Results indicate that employee satisfaction experience improved after the implementation of a balanced scorecard in the Performance Management System. Moreover, the mediating role of the Performance Management System in the relationship between the Balance Score Card and Employee Satisfaction was also partially proved.
\end{abstract}

Keywords: Balanced Scorecard; Performance Management System; Employee Satisfaction.

JEL Code: J28, M11, M41, M52

\section{Introduction}

Employees are the most important asset in an organization and the management needs to keep motivating them to succeed (Hung, 2012). Managing the performance of the employees and giving them periodic feedback aids in enhancing their performance. It also motivates employees to exploit the available opportunities which contribute to their satisfaction (Jamil \& Mohammed, 2011). This in turn leads to the achievement of both strategic and tactical objectives of the organization (Malina, Nørreklit \& Selto, 2007). According to Gupta and Upadhyay (2012), the performance management system of an organization should have the ability to motivate employees as well as improve their performance and satisfaction level. Balanced scorecard (BSC) is a tool that measures performance of a firm along multiple dimensions (Kaplan \& Norton, 1992). Balanced scorecard is popular

\footnotetext{
${ }^{1}$ Institute of Business \& Management, University of Engineering \& Technology, Lahore

${ }^{2}$ School of Business and Economics, University of Management \&Technology, Lahore

Corresponding Author: sophiakhalid@ymail.com
} 
among managers due to its simplicity and multi-disciplinary focus (Akkermans \& Van Oorschot, 2005). This framework is consistent with the suggestions of different researchers such as Dixon, Nanni and Vollman (1990) and Daly (1996) who believed that an evaluation system that measures multiple performance dimensions is more effective as compared to the one that only measures the financial dimensions. Inclusion of non-financial indicators extends the scope of performance measurement system and financial measures solely may not give a clear picture (Narayanamma, 2017). Balanced scorecard makes the performance evaluation process more general (Bazrkar, Iranzadeh, \& Farahmand, 2018) and it enables a firm to monitor its financial and non-financial performance viz a viz the set objectives (Mehralian et al., 2017). It has established itself as a comprehensive performance measurement framework and a new strategic management approach (Bazrkar, Iranzadeh, \& Farahmand, 2018).

A balanced scorecard is designed to give feedback to employees. Over the years, it has helped firms to improve their performance as well as enhance employee's job satisfaction. However, it is not clear how a balanced scorecard achieves this. Most studies on balance scorecards have focused on customer satisfaction. But, surprisingly, the satisfaction of employees is somewhat ignored. In addition, the majority of the research on the balanced scorecards were conducted in the context of large organizations. However, within these studies, Fast Moving Consumer Goods Companies (FMCGs) have limited attention. To the best of authors' knowledge, no study about the effects of a balanced scorecard has been previously carried out in the FMCG sector of Pakistan.

Although a balanced scorecard is established as an effective performance management system, very little empirical work has been conducted to study the relationship between a balanced scorecard, performance management system, and employee's job satisfaction. Traditionally, performance measurement tools, and related research on these, emphasize more on financial aspects. However, the individual effect of both financial and non-financial indicators on the performance management system has received little attention.

Therefore, our research questions are:

1. What is the relationship between the balanced scorecard and employee job satisfaction?

2. Does the performance management system mediate the relationship between balance scorecard and employee job satisfaction?

There are two main objectives of this paper. The first one deals with studying the strategic process and implementation of a balanced scorecard among the FMCGs of Pakistan; whereas the second one aims to measure the effect of a balanced scorecard in measuring the performance of firms and its subsequent effect on employee's satisfaction. In this way, this study attempts to establish the importance of different factors in the balanced scorecard within the larger performance management system. Also, it focuses on the role of a balanced scorecard in improving the satisfaction level of the employees.

For this purpose, data using the survey method was collected from the FMCG sector of Pakistan. To the best of author's knowledge, very few studies have been

Sukkur IBA Journal of Management and Business - SIJMB | Vol 7 No. 1 January - June 2020 @ Sukkur IBA University 
conducted in the context of Pakistan to study the implementation of the balanced scorecard and its subsequent effect on the performance. Drawing on the theory of organizational justice, equity theory of motivation, and expectancy theory, this paper tests the implementation of a balanced scorecard in the performance management system of the FMCG sector of Pakistan. By doing so, this study contributes to the extant literature by developing a logical relationship between a balanced scorecard, performance management system, and job satisfaction of employees.

\section{Literature Review}

\section{Balanced Scorecard}

During the course of time, different frameworks have been proposed within the performance management system. The balanced scorecard is one of the many performance measures which has been derived from the strategy of the organization and implemented successfully around many organizations in the world (Malina, Nørreklit and Selto, 2007). The concept of a balanced scorecard was proposed by Kaplan and Norton in the early 1990s (Baporikar, 2015). According to them, a "balanced scorecard translates an organization's mission and strategy into a comprehensive set of performance measures that provides the framework for a strategic measurement and management system." (Kaplan \& Norton, 1992). The balanced scorecard keeps a watch on whether the short term and long term objectives of the organization are being met or otherwise. It guides an organization towards achieving a desirable future state. The framework of the BSC measures the economic and operating performance of the firm. The balanced scorecard includes a set of financial and non-financial measures that are part of the strategy executing the procedure of an organization. Thus, it communicates the strategy of the organization to employees and provides feedback to managers regarding the achievement of the organization' goals.

Initially, the balanced scorecard was designed to be used as a simple performance measurement framework. But, it has now evolved into a strategic planning system of management. The balanced scorecard acts as a system of management and measurement simultaneously. It also enables managers to put both vision and strategy into action. Due to its popularity, it is equally used in small and large firms. Silk (1998) and Rigby (2009) report that a balanced scorecard is used by around $60 \%$ of large US-based firms and $53 \%$ of worldwide firms. Also in terms of manager's satisfaction, BSC is among the top six managerial tools (Cooper, Ezzamel, \& Qu, 2017). This shows that a balanced scorecard has established their importance in organizations because it is easier for organizations to implement them within different departments and its ability to achieve goals of the organization by combining tangible and intangible goals (Chand et al., 2005; Shen, Chen, \& Wang, 2016).

A balanced scorecard gives a more holistic view of the firm's performance because both financial and non-financial measures are considered in it. BSC is based on the assumption to balance cause-and-effect relationship i.e. the leading measures such as non-financial ones lead to achieving lagging financial measures (Akkermans \&

Sukkur IBA Journal of Management and Business - SIJMB | Vol 7 No. 1 January - June 2020 @ Sukkur IBA University 
Van Oorschot, 2005; Malagueño, Lopez-Valeiras, \& Gomez-Conde, 2018; Nørreklit, Kure, \& Trenca, 2018). It consists of four perspectives which include financial perspective, customer perspective, internal business perspective, and learning and growth perspective. The financial perspective follows the traditional emphasis on performance management on the financial aspect of a firm's performance (Baporikar, 2015). With the rise of Service-Dominant Logic and the concept of value co-creation, the customer perspective focuses on the needs of the customers and their satisfaction. This perspective may be extended to include stackholders and society (Greiling, 2010). Internal business perspective measures critical internal activities as well as efficient and effective ways to manage these activities (Panicker \& Seshadri, 2013). Lastly, the knowledge and learning perspective pertains to training, development, knowledge acquisition, and learning of employees as well as the cultural attitude of the entire organization (Amirkhani, Nazeryani, \& Faraz, 2016; Gawankar, Kamble, \& Raut, 2015).

\section{Performance Management}

Performance management is defined as "the measurement and management of employee performance aimed at increasing organizational effectiveness" (Dewettinck \& van Dijk, 2013, p. 806). It is a multi-level concept which may include individuals, teams, departments, and organization (Yadav \& Dabhade, 2013). Performance management entails a number of activities such as setting performance expectations, observing employee's performance, developing performance evaluations, delivering feedback, and performance coaching, etc. Through these activities, the performance management system is a mechanism to measure individual and organizational performance (Burney \& Matherly, 2007) as well as giving feedback to the employees regarding their performance. This is an attempt to get things done correctly from employees with the right kind of behavior. Unfortunately, many organizations fail to achieve this and ultimately are not able to achieve their strategic goals and objectives. For performance management to be successful, organizational behavior should be developed so that the performance and behavior of the employees could be monitored, controlled, and modified in a way that they can meet the overall aims and objectives of the organization (Jamil \& Mohammed, 2011). The success of a performance management system is correlated with the employees' expectations of how accurate the feedback on their performance would be given (Hung, 2012). If the expectations of the employees are met, the relationship with their performance would be positive (Malina, Nørreklit $\&$ Selto, 2007). Another important thing to consider while developing the performance management system is that it should be in accordance with the employees and their organizational capability so that the system can work at its maximum efficiency and effectiveness (Gupta \& Upadhyay, 2012). The right type of performance management system would check, monitor, and control the performance of employees from all dimensions. The balanced scorecard checks the performance of employees from various dimensions; however, its effectiveness could only exist if it implemented with its real soul. Only then will the system have positive outcomes like enhanced employee performance, commitment, and satisfaction.

Sukkur IBA Journal of Management and Business - SIJMB | Vol 7 No. 1 January - June 2020 @ Sukkur IBA University 


\section{Employee's Job Satisfaction}

Employee satisfaction is considered as a very important and crucial variable in organizational behavior studies. It can also refer to an employee's overall attitude towards his job or the level of contended an employee feels over his job. Employee's job satisfaction is the mental, physical, and environmental satisfaction of employees related to their job. Job satisfaction forms a very vital base of the company's overall performance and the company's general relations. Employee satisfaction is an important variable at all levels of the organization since only a satisfied employee would perform well at the job and would contribute to the overall effectiveness and success of the company. Generally, job satisfaction being less among employees would make them leave their jobs as compared to those satisfied. To achieve employee satisfaction, the employee should be given the right amount of salary and benefits, proper training opportunities, and the right appraisal and feedback on their performance (Gupta \& Upadhyay, 2012).

\section{Conceptual Framework and Research Hypothesis}

A balanced scorecard is an explicitly described performance measurement system that makes it suitable to evaluate the performance of an organization (Shen, Chen, \& Wang, 2016). It takes into consideration present measures and future drivers of performance at the same time (Kerai \& Saleh, 2017). Within the performance measurement system, a balanced scorecard enables a firm to convert its strategy into objectives (Narayanamma, 2017; Nørreklit, Kure, \& Trenca, 2018). Therefore, BSC is believed to positively influence the performance of a firm (Malagueño, Lopez-Valeiras, \& Gomez-Conde, 2018). Therefore, it could be hypothesized that the implementation of BSC as an evaluation system in an organization could impact its performance management system (Risher, 2003).

A balanced scorecard establishes a culture of accountability and control in the organization. When BSC is implemented in any organization, it gives rise to a culture of open communication and sharing. In the context of performance measurement, employees are actively involved in setting organizational objectives. This reduces any doubts related to the job which results in greater satisfaction level for them (Ángel Calderón Molina et al. 2014). Employees have a better understanding of organizational strategy due to the implementation of a balanced scorecard and they feel more satisfied with their job (Alhyari et al., 2013). Moreover, Decramer, Smolders, and Vanderstraeten (2013) have demonstrated that a higher level of internal consistency in the performance measurement system is related to job satisfaction among employees. This means that an effective performance measurement system of any organization contributes to a higher level of employee satisfaction.

This study extends this line of reasoning by suggesting that the implementation of a balanced scorecard in the performance management system creates a sense of procedural, informational, and interactional justice among employees. The literature on organizational justice and equity theory of motivation informs that employees are motivated by fairness in the organizational activities and procedures. Similarly, expectancy theory postulates that individuals tend to spend more energy and time on actions they perceive to be more satisfactory (Dewettinck \& van Dijk,

Sukkur IBA Journal of Management and Business - SIJMB | Vol 7 No. 1 January - June 2020 @ Sukkur IBA University 
2013). Sharma, Sharma, and Agarwal (2016) warn that the success of any performance measurement system depends upon its credibility among employees. A balanced scorecard provides multiple performance feedback to the employees that improve their satisfaction by giving a sense of justice and equity.

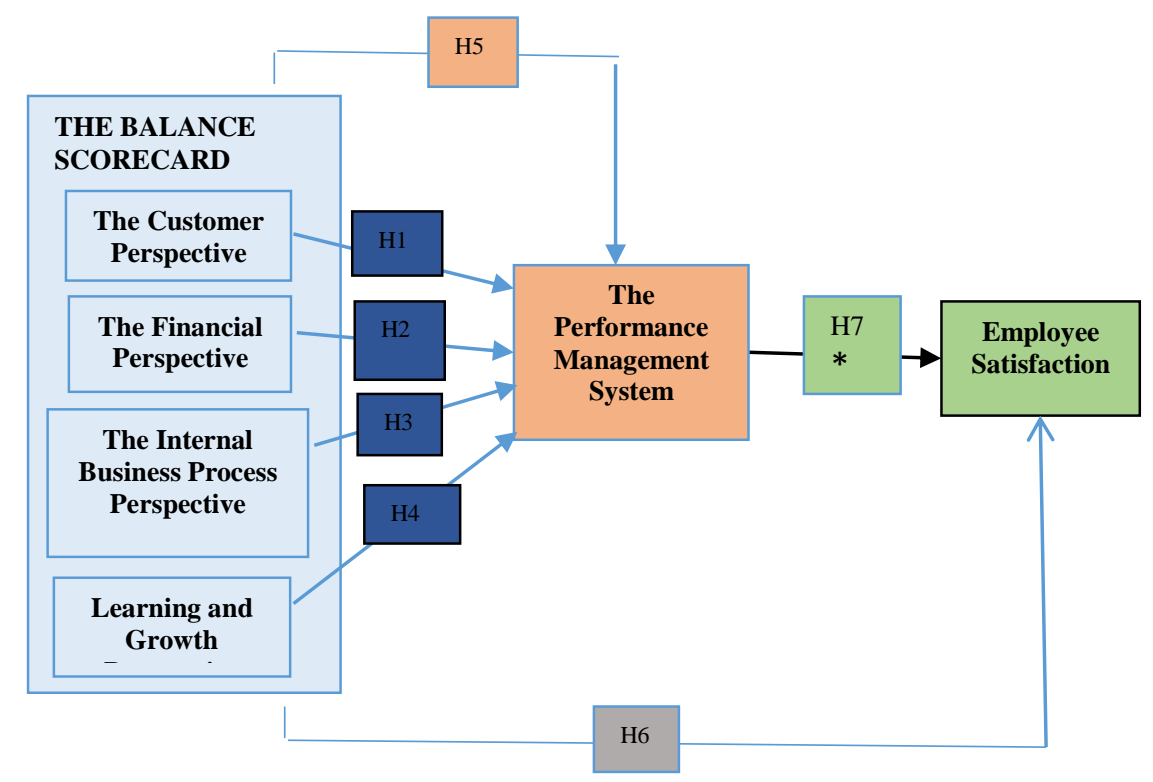

Based on the above discussion, our research hypotheses are:

H1: The customer perspective of BSC has a positive impact on the Performance Management System.

H2: The financial perspective of BSC has a positive impact on the performance management system.

H3: The internal business process perspective of BSC has a positive impact on the performance management system.

H4: The learning and growth perspective of BSC has a positive impact on the performance management system.

H5: The balanced scorecard has a positive impact on the performance management system.

H6: The balanced scorecard has a positive impact on employee satisfaction.

H7: The improvement in the performance management system has a positive impact on employee satisfaction.

H8: The relationship between the balanced scorecard and employee satisfaction is mediated by the performance management system.

\section{Research Methodology}

The research approach that was used in the present study is deductive where a detailed literature review was conducted on the basis of which a theoretical framework of the study was developed (Bryman \& Bell, 2003). The research hypotheses were formulated from the conceptual framework; that were tested via Sukkur IBA Journal of Management and Business - SIJMB | Vol 7 No. 1 January - June 2020 ○ Sukkur IBA University 
the collection of empirical evidence (Saunders, Lewis \& Thornhill, 2007). Moreover, the design of the research was explorative as the study aimed to explore the impact of the BSC implementation of the performance management system and employee satisfaction at the FMCG Sector of Pakistan.

A research instrument designed based on a literature review was used to collect data. The five-point Likert scale was the basis of the instrument. It included choices like strongly agree, agree, neither agree nor disagree, disagree, and strongly disagree. A close-ended questionnaire was distributed among the employees at different FMCGs of Pakistan. The employee was chosen as a unit of analysis following the suggestion of Sharma, Sharma, and Agarwal (2016) who stresses the need to study the performance management system from the perspective of employees.

Hair et al (1998) recommend that for determining sample size, the ratio between observations to items should not fall below 5:1. This means that for each item in the questionnaire there should be five observations or respondents. Since the questionnaire contained a total of 39 items; therefore, the sample size should not be below 195. A provision of $10 \%$ was kept for any incomplete, wrong, or unattended questionnaire. A sample of 240 respondents was selected on the basis of convenience sampling and the respondents were asked to fill in the questionnaire. However, 218 questionnaires were duly completed and received back. This means a response rate of $90.83 \%$.

\section{Results and Discussions}

The majority of the respondents $(66.972 \%)$ were clerical staff; while $11.926 \%$, $12.844 \%$, and $8.257 \%$ were supervisory staff, middle-level management, and senior-level management respectively. Most of the employees had worked for 6 to 10 years representing $42.66 \%$. $33.027 \%$ of the respondents had worked for 1 to 5 years, $17.431 \%$ for 11 to 15 years while $6.881 \%$ had served for 16 to 20 years. It is an indication that the majority of the employees in FMCGs (66.3\%) had worked in the company for more than 5 years. They were, hence, in a better position to give information as sought by the study as they had adequate experience with the working of their respective company. The majority of the respondents $(47.248 \%)$ had a first degree $25.229 \%$ had the education to masters' level, $14.678 \%$ had diplomas and only $12.844 \%$ had certificates. This was a plus point of the research that the respondents had adequate education and therefore were in a position to give reliable information as sought by this study.

\section{Hypothesis Testing}

Regression analysis using the Ordinary Least Square (OLS) method was used to test the research hypothesis. For this purpose, different regression models were developed after fulfilling the requisite conditions of regression analysis. Following the suggestions of Mendenhall, Sincich, \& Boudreau (2012), all the requisite conditions of regression i.e. normality of data, auto-correlation, multi co-linearity were tested and these were fulfilled.

The results of these models are shown in Table No 1.

Sukkur IBA Journal of Management and Business - SIJMB | Vol 7 No. 1 January - June 2020 @ Sukkur IBA University 
Hypothesis No. 1: Our first hypothesis predicted a positive relationship between customer perspective and performance management system. As evident from Model, No 1 given in Table No 1, the un-standardized coefficient between both the variables bears a positive sign. Moreover, the same was statistically significant at a $\mathrm{p}<0.01$. This was proved as there was a positive and significant relationship between both the variables. However, a relatively weak association was found between both the value of $\mathrm{R} 2$ for this model was low.

Hypothesis No. 2: Similarly, our second hypothesis was also proved as a significant and positive relationship was found between financial perspective and performance management system. The value of the un-standardized coefficient for this model is 0.689 (Model No 2) which is significant at $\mathrm{p}<1 \%$. The value of R2 for this model is 0.536 which means that nearly $53 \%$ variation in the value of performance management can be predicted by a financial perspective.

Hypothesis No. 3: Likewise, a moderate association was found between the internal business process perspective and performance management system which was also statistically significant at a p-value below 0.01 . The value of the unstandardized coefficient for this relationship is 0.747 ; thereby confirming the presence of a positive relationship between both variables (Model No 3).

Hypothesis No. 4: As predicted in the fourth hypothesis, learning and growth perspective score was positively related to the performance management system. The value of $\mathrm{R} 2$ for this regression model is 0.821 which indicates the presence of a strong relationship between the predictor and the outcome (Model No 4). Moreover, this association was also statistically significant at a p-value below $1 \%$. Therefore, our fourth hypothesis was also supported.

Table 1: Relationship of different predictors with the performance management system

\begin{tabular}{|c|c|c|c|c|c|}
\hline Name of Variable & Model 1 & Model 2 & Model 3 & Model 4 & Model 5 \\
\hline Customer Perspective Score & $\begin{array}{r}0.568^{* * *} \\
(0.050)\end{array}$ & & & & \\
\hline Financial Perspective Score & & $\begin{array}{r}0.689^{* * *} \\
(0.045)\end{array}$ & & & \\
\hline $\begin{array}{l}\text { Internal Business Process } \\
\text { Perspective Score }\end{array}$ & & & $\begin{array}{r}0.747^{* * * *} \\
(0.045)\end{array}$ & & \\
\hline $\begin{array}{l}\text { Learning \& Growth } \\
\text { Perspective Score }\end{array}$ & & & & $\begin{array}{r}0.892^{* * *} \\
(0.029)\end{array}$ & \\
\hline Balanced Scorecard Score & & & & & $\begin{array}{r}0.879^{* * *} \\
(0.038)\end{array}$ \\
\hline Value of $\mathrm{R}^{2}$ & $0.39^{* * *}$ & $0.536^{* * * *}$ & $0.566^{* * *}$ & $0.821^{* * *}$ & $0.722^{* * *}$ \\
\hline
\end{tabular}

Hypothesis No. 5: Also, in the last case, the balance scorecard score has a moderate relationship with the performance management system at $\mathrm{p}$-value $<0.001$. Positive sign with un-standardized coefficient means that the relationship between Sukkur IBA Journal of Management and Business - SIJMB | Vol 7 No. 1 January - June 2020 ○ Sukkur IBA University 
Sophia Khalidi et al Contribution of Balanced Scorecard Implementation in Performance Management System to Enhance Job Satisfaction: Empirical Evidence from FMCG Sector of Pakistany

both the antecedent and outcome variable was positive. This means that our fifth hypothesis is also proved (Model No 5).

Testing of the mediating role of performance management in the relationship between the balanced scorecard and employee satisfaction - Baron and Kenny Method

The second part of the study investigates the mediating role of performance management in the relationship between balance scorecard and employee satisfaction. For this purpose, Baron and Kenny (1986) approach were used to test this mediation. According to this method, the mediation is established in four steps described as under:

\section{Step I}

In the first step, the direct relationship between the independent variable (I.V) and the dependent variable (D.V) is determined.

\section{Step II}

In the second step, the correlation between the independent variable (I.V) and the mediating variable (M.V) is tested.

\section{Step III}

Then, the mediating variable (M.V) is correlated with the dependent variable.

\section{Step IV}

In the last step, the effect of the independent variable on the dependent variable is tested by controlling the mediating variable.

If in this last step, the mediator is significant while the independent variable becomes insignificant; then full mediation is proved. However, if both the independent variable and the mediator remain statistically significant, then partial mediation is established. If the independent variable is statistically significant but mediating one is not; this means that the mediation is not proved.

For this study, the above discussion can be summarized as under:

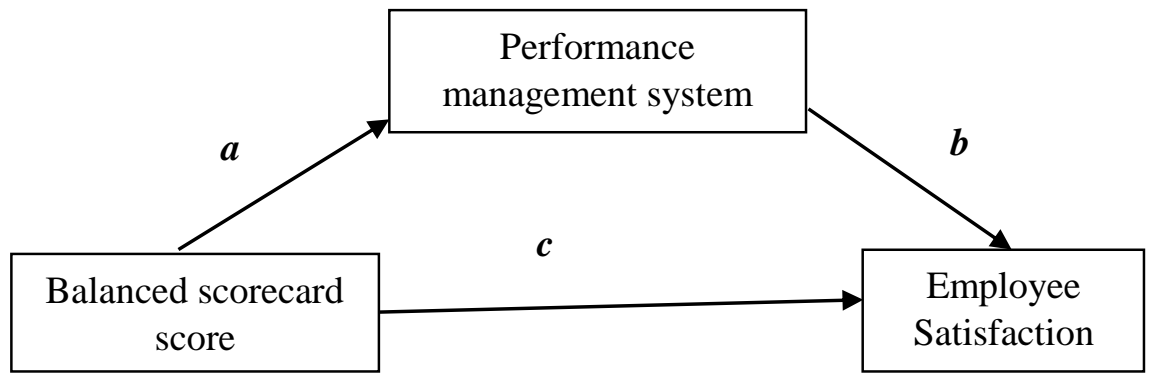

Figure 1: Baron and Kenny Approach (Author's Developed)

Hypothesis No. 6 (Step- I): Following this approach, we have first tested the direct relationship of a balanced scorecard score with employee satisfaction. The result presented in Table 2 shows that both are significantly related (Model No 6). This supports the Research work of Ángel Calderón Molina et al. (2014) who have

Sukkur IBA Journal of Management and Business - SIJMB | Vol 7 No. 1 January - June 2020 @ Sukkur IBA University 
Sophia Khalidi et al Contribution of Balanced Scorecard Implementation in Performance Management System to Enhance Job Satisfaction: Empirical Evidence from FMCG Sector of Pakistany

highlighted that implementation of BSC in a firm is positively related to employees' affective reactions such as their commitment, job satisfaction, and job dedication.

Table 2: Relationship of the balanced scorecard (I.V) with employee satisfaction

$$
\text { (D.V) }
$$

\begin{tabular}{|l|c|}
\hline & Model 6 \\
\hline Balanced scorecard score & $0.924^{* * *}$ \\
& $(0.044)$ \\
\hline Value of $\mathrm{R}^{2}$ & $0.688^{* * *}$ \\
\hline
\end{tabular}

Step-II: As shown in table 2, the independent variable viz balanced scorecard is positively and significantly associated with the mediating variable namely performance management score. This proves the path "a" positive and significant relationship exists between balance score care and performance management.

Table 3: Relationship of the balanced scorecard (I.V) with performance management system (M.V)

\begin{tabular}{|l|c|}
\hline & Model 7 \\
\hline Balanced scorecard score & $\begin{array}{c}0.879^{* * *} \\
(0.038)\end{array}$ \\
\hline Value of $\mathrm{R}^{2}$ & $0.722^{* *}$ \\
\hline
\end{tabular}

Hypothesis No. 7 (Step-III): In the third step, the relationship between mediator (M.V) and outcome (D.V) is tested. Table No 4 illustrates that performance management is positively related to employee satisfaction at $p<0.01$. This establishes the existence of a relationship between the mediating variable and the dependent variable. (Model 8)

Table 4: Relationship of the performance management system (M.V) with employee satisfaction (D.V)

\begin{tabular}{|l|c|}
\hline & Model 8 \\
\hline Performance management system & $0.942^{* * *}$ \\
& $(0.027)$ \\
\hline Value of $\mathrm{R}^{2}$ & $0.850^{* * *}$ \\
\hline
\end{tabular}

Hypothesis No. 8 (Step-IV): In the last step, both independent variable and mediator are regressed on the dependent variable at the same time to test path $\mathrm{c}$.

Sukkur IBA Journal of Management and Business - SIJMB | Vol 7 No. 1 January - June 2020 ( ) Sukkur IBA University 
Table No 5 shows that both the independent variable and mediator are statistically significant. Partial mediation was thus proved.

Table No 5: Mediating role of performance management system on the relationship between balanced scorecard (I.V) and employee satisfaction (D.V)

\begin{tabular}{|l|c|}
\hline Name of Variable & \\
\hline Balanced scorecard Score & $0.236^{* * *}$ \\
\hline Performance Management Score & $(0.054)$ \\
\hline Value of $\mathrm{R}^{2}$ & $0.806^{* * *}$ \\
& $(0.042)$ \\
\hline
\end{tabular}

\section{Sobel Test and Indirect Effect}

Baron and Kenny method as described above was used to test the existence of the mediating role of performance management system score on the relationship between the balanced scorecard and employee satisfaction performed. However, this test could not calculate the direct, indirect, and total effect of a balanced scorecard on employee satisfaction. Another problem with this approach is the lack of ability to predict the level of significance of the indirect pathway.

For this paper, the Sobel test was performed through PROCESS MACRO developed by Andrew F. Hayes and his colleagues (Preacher \& Hayes, 2004). First of all the direct effect between the balanced scorecard and employee satisfaction was calculated. The value of direct effect was calculated to be 0.2358 which means that a change of 0.24 units will be produced in the value of employee satisfaction for every unit change in a balanced scorecard. Moreover, this effect was statistically significant at a p-value of less than $1 \%$.

Table 6: Direct effect between balanced scorecard (I.V) and employee satisfaction (D.V)

\begin{tabular}{|c|c|c|c|c|c|}
\hline Effect & SE & $\mathrm{t}$ & $\mathrm{p}$ & LLCI & ULCI \\
\hline .2358 & .0615 & 3.8348 & .0002 & .1146 & .3569 \\
\hline
\end{tabular}

After that, the indirect effect was calculated which tests how much our independent variable affects the dependent variable through the compound of both IV and Mediator. In our case, the coefficient of the regression coefficient for this indirect effect represents the change in the value of employee satisfaction for every unit change in a balanced scorecard that is mediated by performance management score. Since the value of this coefficient is 0.7942 this means that a unit change in the value of balance scorecard will produce a change of nearly 0.80 units in the value of employee satisfaction when the mediating effect of the performance management system is considered. The value of the coefficient in indirect effect was higher as compared to direct one, emphasizing that the mediator viz performance management score is making the relationship between balance scorecard and employee satisfaction stronger.

Sukkur IBA Journal of Management and Business - SIJMB | Vol 7 No. 1 January - June 2020 ○ Sukkur IBA University 
Table 7: Indirect effect of the balanced scorecard (I.V) on employee satisfaction

(D.V)

\begin{tabular}{|l|l|l|l|l|}
\hline & Effect & Boot SE & BootLLCI & BootULCI \\
\hline Prf_MGT & .7942 & .0868 & .6060 & .9554 \\
\hline
\end{tabular}

Lastly, the total effect size of both predictor and mediator on the outcome variable was calculated. This value is the sum of coefficients of the direct and indirect effects. This was also statistically significant at $\mathrm{p}<0.01$.

Table 8: Total effect of the balanced scorecard (I.V) on employee satisfaction

(D.V)

\begin{tabular}{|l|l|l|l|l|l|}
\hline Effect & SE & $\mathrm{t}$ & $\mathrm{p}$ & LLCI & ULCI \\
\hline 1.0299 & .0717 & 14.3580 & .0000 & .8885 & 1.1713 \\
\hline
\end{tabular}

\section{Discussion on Results}

Every firm attempts to achieve higher performance. Since the introduction of the framework of the balanced scorecard proposed by Kaplan and Norton (1992), there is an increasing interest by the managers and researchers in BSC. A balanced scorecard is increasingly becoming important for modern organizations due to its ability to support the implementation of the firm's strategy. Successful deployment and use of a balanced scorecard improve the financial performance of any organization as established by the finding of Malagueño, Lopez-Valeiras, and Gomez-Conde (2018). Within the performance management system, a balanced scorecard holds a unique position due to its equal focus on both financial and nonfinancial indicators. The traditional measure of a firm's performance emphasizes only financial measures in the short run. But, a balanced scorecard extends the boundary of the firm's performance measurement system and attempts to balance external measures such as customers and internal measures like learning and growth perspective (Chavan, 2009; Nørreklit, Kure, \& Trenca, 2018).

A balanced scorecard in firms is considered to lead towards the development of new capabilities. Among different performance measurement frameworks, a balanced scorecard is unique due to stress on learning and growth, and acquisition of new capabilities and skills. The learning and growth perspective within BSC emphasizes the acquisition of new capabilities and skills, which is essential to survive in today's volatile, uncertain, complex, and ambiguous environment. This is achieved through the combination of people and technology to achieve the objectives of the firm (Bazrkar, Iranzadeh, \& Farahmand, 2018). In this way, a balanced scorecard contributes towards employee development and the simultaneous growth of employees and organizations. An organization is able to achieve employee development when it encourages its employees and provide them with different opportunities to nurture their skill sets (Visalakshi \& Kasilingam, 2017). Such employees experience an enhanced satisfaction level and contribute to a higher performance level. 


\section{Conclusion}

The purpose of this paper is to study the contribution of balanced scorecard implementation in the performance management system and its subsequent effect on employee job satisfaction within the FMCG sector of Pakistan. It was purposed that the implementation of a balanced scorecard results in a superior performance management system of the company. This, in turn, improves the job satisfaction of employees since they perceive their job evaluation to be justified and aligned with the organizational objectives.

Results show the performance management system partially mediates the relationship between balance scorecard and employee satisfaction. By doing so, this research develops a logical link between these three constructs which have been studied independently by various authors. This means that FMCGs have reaped benefits from the introduction of the balanced scorecard in terms of customer service, efficiency, employee growth, and profitability that are the major aspects of employee job satisfaction.

This study can be extended by replicating in different sectors for the example banking sector, telecommunication, universities, etc. The results of different sectors can be compared to establish the robustness of the research framework. The framework can be extended by incorporating different variables as mediators and moderators to provide a better understanding of the underlying phenomenon.

\section{References}

Akkermans, H. A., \& Van Oorschot, K. E. (2005). Relevance assumed: a case study of balanced scorecard development using system dynamics. Journal of the Operational Research Society, 56(8), 931-941.

Alhyari, S., Alazab, M., Venkatraman, S., Alazab, M., \& Alazab, A. (2013). Performance evaluation of e-government services using balanced scorecard: An empirical study in Jordan. Benchmarking: An International Journal, 20(4), 512-536.

Amirkhani, A., Nazeryani, M., \& Faraz, M. (2016). The Effect of Succession Planning on the Employees' Performance based on the Balance Score Card with Regard to the Mediating Role of Commitment. Research Journal of Management Reviews, 2(1), 42-51.

Ángel Calderón Molina, M., Manuel Hurtado González, J., Palacios Florencio, B., \& Luis Galán González, J. (2014). Does the balanced scorecard adoption enhance the levels of organizational climate, employees' commitment, job satisfaction and job dedication? Management Decision, 52(5), 983-1010.

Bazrkar, A., Iranzadeh, S., \& Farahmand, N. (2018). Identifying and selecting the strategic process using the cross-efficiency approach based on satisfaction level and extended balanced scorecard. International Journal for Quality Research, 12(1), 81-94.

Bazrkar, A., Iranzadeh, S., \& Farahmand, N. F. (2017). Total quality model for aligning organization strategy, improving performance, and improving customer satisfaction by using an approach based on combination of balanced scorecard and lean six sigma. Cogent Business \& Management, 4(1), 1390818.

Baporikar, N. (2015). Adopting Balance Score Card in Higher Education. International Journal of Strategic Information Technology and Applications (IJSITA), 6(2), 1-11.

Baron, R. M., \& Kenny, D. A. (1986). The moderator-mediator variable distinction in social psychological research: Conceptual, strategic, and statistical considerations. Journal of Personality and Social Psychology, 51(6), 1173.

Bryman, A., \& Bell, E. (2003).Business research methods: Oxford University Press, USA.

Sukkur IBA Journal of Management and Business - SIJMB | Vol 7 No. 1 January - June 2020 (C) Sukkur IBA University 
Sophia Khalidi et al Contribution of Balanced Scorecard Implementation in Performance Management System to Enhance Job Satisfaction: Empirical Evidence from FMCG Sector of Pakistany (pp. 40-54)

Burney, L. L., \& Matherly, M. (2007). Examining performance measurement from an integrated perspective. Journal of Information Systems, 21(2), 49-68.

Chand, D., Hachey, G., Hunton, J., Owhoso, V., \& Vasudevan, S. (2005). A balanced scorecard based framework for assessing the strategic impacts of ERP systems. Computers in Industry, 56(6), 558-572.

Chavan, M. (2009). The balanced scorecard: a new challenge. Journal of Management Development, 28(5), 393-406.

Cooper, D. J., Ezzamel, M., \& Qu, S. Q. (2017). Popularizing a management accounting idea: The case of the balanced scorecard. Contemporary Accounting Research, 34(2), 991-1025.

Daly, D. C. (1996).Performance measurement and management. Strategic Finance, 78(3), 65.

Decramer, A., Smolders, C., \& Vanderstraeten, A. (2013). Employee performance management culture and system features in higher education: relationship with employee performance management satisfaction. The International Journal of Human Resource Management, 24(2), 352-371.

Dewettinck, K., \& van Dijk, H. (2013). Linking Belgian employee performance management system characteristics with performance management system effectiveness: exploring the mediating role of fairness. The International Journal of Human Resource Management, 24(4), 806-825.

Dixon, J. R., Nanni, A., \&Vollmann, T. E. (1990).The new performance challenge: measuring operations for world class performance. Homewood, IL: Dow Jones Irwin.

Gawankar, S., Kamble, S. S., \& Raut, R. (2015). Performance Measurement Using Balance Score Card and its Applications: A Review. Journal of Supply Chain Management Systems, 4(3), 6-22.

Greiling, D. (2010). Balanced scorecard implementation in German non-profit organizations. International Journal of Productivity and Performance Management, 59(6), 534-554.

Gupta, A., \& Upadhyay, D. (2012).Impact of effectiveness of performance management system on employee satisfaction and commitment. International Journal of Management, IT and Engineering, 2(7), 96-106.

Hair, J. F., Anderson, R. E., Tatham, R. L., \& Black, W. C. (1998). Multivariate data analysis (5th ed.): Prentice hall Upper Saddle River, NJ.

Hung, Y. W. (2012). Constructing a strategy map for banking institutions with key performance indicators of the balanced scorecard. Evaluation and Program Planning, 35(3), 303-320.

Jamil, C., \& Mohamed, R. (2011). Performance measurement system (PMS) in small medium enterprises (SMES): A practical modified framework. World Journal of Social Sciences, 1(3), 200-212.

Kaplan, R. S., \& Norton, D. P. (1992). The Balance Scorecard - Measures That Drive Performance. Harvard Business Review, 70(1), 71-79.

Kerai, S., \& Saleh, A. (2017). Applying the Balanced Scorecard to Improve Student Satisfaction, Market Share and Profitability. The Applied Management Review, 1(1), 27-38.

Malagueño, R., Lopez-Valeiras, E., \& Gomez-Conde, J. (2018). Balanced scorecard in SMEs: effects on innovation and financial performance. Small Business Economics, 51(1), 221-244.

Malina, M. A., Nørreklit, H. S., \& Selto, F. H. (2007).Relations among measures, climate of control, and performance measurement models. Contemporary Accounting Research, 24(3), 935-982.

Sukkur IBA Journal of Management and Business - SIJMB | Vol 7 No. 1 January - June 2020 @ Sukkur IBA University 
Mehralian, G., Nazari, J. A., Nooriparto, G., \& Rasekh, H. R. (2017). TQM and organizational performance using the balanced scorecard approach. International Journal of Productivity and Performance Management, 66(1), 111-125.

Mendenhall, W., Sincich, T., \& Boudreau, N. S. (2012).A second course in statistics: regression analysis (7th ed.). Upper Saddle River, NJ: Prentice Hall

Narayanamma, P. L. (2017). A Study On Impact of Balanced Scorecard Implementation On Job Satisfaction Of Employees In Selected Public And Private Sector. Shanlax International Journal of Arts, Science and Humanities, 4(3), 44-52.

Nørreklit, H., Kure, N., \& Trenca, M. (2018). Balanced Scorecard. In R. L.Heath \& W. Johansen (Eds.), The International Encyclopedia of Strategic Communication (pp. 16): John Wiley \& Sons.

Panicker, S., \& Seshadri, V. (2013). Devising a balanced scorecard to determine Standard Chartered Bank's Performance: A case Study. International Journal of Business Research and Development, 2(2), 35-42.

Preacher, K. J., \& Hayes, A. F. (2004).SPSS and SAS procedures for estimating indirect effects in simple mediation models. Behavior Research Methods, Instruments, \& Computers, 36(4), 717-731.

Rigby, D. (2009). Management tools \& trends 2009. London: Bain \& Company.

Risher, H. (2003). Refocusing performance management for high performance. Compensation \& Benefits Review, 35(5), 20-30.

Saunders, M., Lewis, P., \& Thornhill, A. (2007). Research methods for business students. Harlow, New York: Prentice Hall.

Schleicher, D. J., Baumann, H. M., Sullivan, D. W., Levy, P. E., Hargrove, D. C., \& BarrosRivera, B. A. (2018). Putting the system into performance management systems: A review and agenda for performance management research. Journal of Management, 44(6), 2209-2245.

Sharma, N. P., Sharma, T., \& Agarwal, M. N. (2016). Measuring employee perception of performance management system effectiveness: Conceptualization and scale development. Employee Relations, 38(2), 224-247.

Shen, Y. C., Chen, P. S., \& Wang, C. H. (2016). A study of enterprise resource planning (ERP) system performance measurement using the quantitative balanced scorecard approach. Computers in Industry, 75, 127-139.

Silk, S. (1998). Automating the balanced scorecard. Strategic Finance, 79(11), 38-44.

Visalakshi, S., \& Kasilingam, R. (2017). Learning and growth perspective of the balanced scorecard in commercial banks in India. Psychological Researches, 60(1), 28-37.

Yadav, R. K., \& Dabhade, N. (2013). Performance management system in Maharatna Companies (a leading public sector undertaking) of India-a case study of BHEL, Bhopal (MP). International Letters of Social and Humanistic Sciences, 4(49), 49-69. 